Vol. 1 No. 4 Oktober 2021 e-ISSN : 2774-6283 | p-ISSN : 2775-0019

\title{
PEMANFAATAN EDMODO UNTUK MENINGKATKAN AKTIFITAS DAN HASIL BELAJAR SISWA SMKN 1 GUNUNGPUTRI PADA SAAT PRAKTEK KERJA LAPANGAN (PKL)
}

\author{
TRIAN FITRIYANI \\ Pascasarjana PMIPA, Universitas Indraprasta PGRI, Jakarta \\ e-mail: fitriyanitrian02@gmail.com
}

\begin{abstract}
ABSTRAK
Salah satu program pembelajaran di SMK yang secara khusus diprogramkan untuk diselenggarakan di masyarakat atau industri adalah Praktik Kerja Lapangan (PKL). Program ini merupakan ciri khas dari SMK yang membedakannya dengan SMA. Namun ada beberapa hambatan yang ditemui, salah satu hambatan kegiatan PKL di SMKN 1 Gunungputri adalah jumlah tempat PKL yang tidak sesuai dengan jumlah siswa yang akan PKL. Institusi pasangan/Industri di sekitar SMKN 1 Gunungputri belum bisa menampung sejumlah siswa PKL dari SMKN 1 Gunungputri sehingga pelaksanaan PKL di SMKN 1 Gunungputri tidak bisa menggunakan sistem blok. Ketidakseragaman metode pembelajaran yang didapatkan siswa menjadi sebuah masalah, Siswa yang sedang menjalani PKL dan diharapkan bisa belajar mandiri cenderung acuh, tidak ada kemauan untuk belajar mandiri akibatnya aktivitas pembelajaran dan hasil belajar siswa yang sedang PKL menurun. Untuk mengatasi hal tersebut, guru menggunakan salah satu flatform e-learning yang disebut Edmodo. Tujuan penelitian ini adalah memberikan gambaran bagaimana pemanfaatan Edmodo untuk meningkatkan aktivitas dan hasil belajar siswa SMKN I Gunungputri pada saat Praktek Kerja Lapangan (PKL). Penelitian menggunakan metode penelitian tindakan kelas (PTK) yang bertujuan untuk mendapatkan strategi yang tepat untuk memanfaatkan Edmodo dalam pembelajaran khususnya untuk siswa yang sedang PKL sehingga diharapkan ada peningkatan aktivitas dan hasil belajar siswa. Berdasarkan hasil penelitian dan analisis data yang dilakukan dapat diketahui bahwa skor aktivitas siswa menunjukkan adanya peningkatan dari skor pada kondisi awal (sebelum adanya tindakan). Skor pada kondisi awal sebesar 45\% dengan kategori kurang aktif menjadi 92\% pada siklus 2 dengan kategori sangat aktif. Peningkatan juga terjadi pada hasil belajar siswa, kondisi awal nilai rata-rata sebesar 66,7 menjadi 72,37 pada siklus 1 dan 80,10 pada siklus 2.
\end{abstract}

Kata Kunci: Edmodo, Aktivitas, Hasil belajar

\section{ABSTRACT}

One of the learning programs in SMK that is specifically programmed to be held in the community or industry is the Field Work Practice (PKL). This program is a hallmark of SMK that distinguishes it from SMA. However, there are several obstacles encountered, one of the obstacles to PKL activities at SMKN 1 Gunungputri is the number of PKL places that are not in accordance with the number of students who will PKL. Couples/Industry institutions around SMKN 1 Gunungputri have not been able to accommodate a number of street vendors from SMKN 1 Gunungputri so that the implementation of street vendors at SMKN 1 Gunungputri cannot use the block system. The non-uniformity of learning methods obtained by students becomes a problem, students who are undergoing street vendors and are expected to be able to study independently tend to be indifferent, there is no willingness to learn independently as a result of decreased learning activities and learning outcomes of students who are street vendors. To overcome this, the teacher uses an e-learning platform called Edmodo. The purpose of this study is to provide an overview of how the use of Edmodo to increase the activities and learning outcomes of students at SMKN I Gunungputri during the Field Work Practice (PKL). The research uses classroom action research (CAR) which aims to get the right strategy to use Edmodo in learning, especially for students who are street vendors so that it is hoped that there will be an increase in student activity and learning outcomes. Based on the results of research 
and data analysis conducted, it can be seen that the student activity scores showed an increase from the scores in the initial conditions (before the action). The score in the initial condition was $45 \%$ in the less active category to $92 \%$ in cycle 2 with the very active category. An increase also occurred in student learning outcomes, the initial condition of the average score was 66.7 to 72.37 in cycle 1 and 80.10 in cycle 2 .

Keywords: Edmodo, Activities, Learning Outcomes

\section{PENDAHULUAN}

Salah satu program pembelajaran di SMK yang secara khusus diprogramkan untuk diselenggarakan di masyarakat atau industri adalah Praktik Kerja Lapangan (PKL). Program ini merupakan ciri khas dari SMK yang membedakannya dengan SMA. Program PKL disusun bersama antara sekolah dan masyarakat (Institusi Pasangan/ Industri) dalam rangka memenuhi kebutuhan peserta didik, sekaligus merupakan wahana bagi dunia kerja (DU/DI) untuk berkontribusi dalam upaya pengembangan sumber daya manusia melalui pendidikan di SMK.

Dalam pelaksanaannya, kegiatan PKL di SMKN 1 Gunungputri menemui beberapa hambatan. Salah satu hambatannya adalah jumlah tempat PKL yang tidak sesuai dengan jumlah siswa yang PKL. Institusi pasangan/Industri di sekitar SMKN 1 Gunungputri belum bisa menampung sejumlah siswa PKL dari SMKN 1 Gunungputri sehingga pelaksanaan PKL di SMKN 1 Gunungputri tidak bisa menggunakan sistem blok. Siswa yang PKL tidak dijadwalkan kapan mereka akan mulai PKL, mereka menunggu kesediaan industri menerima mereka.

Siswa yang mendapatkan kesempatan PKL lebih dulu dari Perusahaan/industri bisa langsung melaksanakan PKL sedangkan yang belum PKL tetap melaksanakan kegiatan pembelajaran disekolah. Sehingga dalam satu kelas ada siswa yang mendapatkan materi langsung dengan tatap muka bersama guru disekolah, ada juga siswa yang harus belajar sendiri melalui modul atau melalui media pembelajaran lainnya. Ketidakseragaman metode pembelajaran yang didapatkan siswa menjadi sebuah masalah. Siswa yang sedang menjalani PKL dan diharapkan bisa belajar mandiri cenderung acuh, tidak ada kemauan atau keinginan untuk belajar mandiri.

Seiring dengan perkembangan Teknologi Informasi (TI) yang semakin pesat, konsep dan mekanisme belajar mengajar berbasis TI bukan menjadi hal yang baru. Konsep yang kemudian terkenal dengan sebutan e-learning ini membawa pengaruh terjadinya proses transformasi pendidikan konvensional ke dalam bentuk digital, baik isi maupun sistemnya. Salah satu flatform e-learning adalah Edmodo.

Menurut Balasubramaniana (2014), Edmodo adalah pembelajaran berbasis jejaring sosial yang aman dan gratis dalam memudahkan guru untuk membuat dan mengelola kelas virtual sehingga siswa dapat terhubung dengan teman sekelas dan guru kapan saja dan dimana saja. Edmodo.com diciptakan menggunakan konsep social networking, yang mengacu pada jejaring sosial Facebook, sehingga sistem ini memiliki fitur yang mirip dengan Facebook. Bahkan banyak yang bilang Edmodo.com adalah Facebook-nya sekolah, karena selain untuk media jejaring sosial/kolaborasi diantara penggunanya, Edmodo juga mendukung proses pembelajaran online. Dalam mendukung proses pembelajaran, Edmodo dilengkapi dengan beberapa aktivitas pembelajaran, seperti Quiz, Assignment dan poll. Untuk bahan ajar edmodo mendukung bahan ajar berupa file dan link.

Berdasarkan latar belakang permasalahan tersebut, maka rumusan permasalahan dalam penelitian ini adalah bagaimana pemanfaatan Edmodo untuk meningkatkan aktivitas dan hasil belajar siswa SMKN I Gunungputri pada saat Praktek Kerja Lapangan (PKL). Penelitian ini bertujuan untuk mendapatkan strategi yang tepat dalam memanfaatkan Edmodo dalam Pembelajaran khususnya untuk siswa yang sedang PKL sehingga diharapkan ada peningkatan aktivitas dan hasil belajar siswa.

Pada kondisi awal aktivitas dan hasil belajar kelas XI Kimia 3 rendah, terutama untuk siswa yang sedang melakukan PKL. Modul pembelajaran yang diberikan sebagai media pembelajaran jarak jauh tidak efektif untuk membuat mereka belajar secara mandiri. Kondisi 
tersebut dijadikan tolok ukur untuk meningkatkan aktivitas pembelajaran dan hasil belajar siswa sehingga didapatkan proses dan hasil pembelajaran yang lebih baik.

\section{METODE PENELITIAN}

Penelitian dilaksanakan di kelas XI Kimia Industri-3 SMK Negeri 1 Gunungputri, pada semester ganjil tahun pelajaran 2016/2017. Metode Penelitian ini menggunakan penelitian Tindakan Kelas (PTK) atau Classroom Action Research. Penelitian ini diadopsi dari penelitian menurut Kurt Lewin yang terdiri dari empat tahapan yang harus dilalui yaitu perencanaan, pelaksanaan, pengamatan dan refleksi

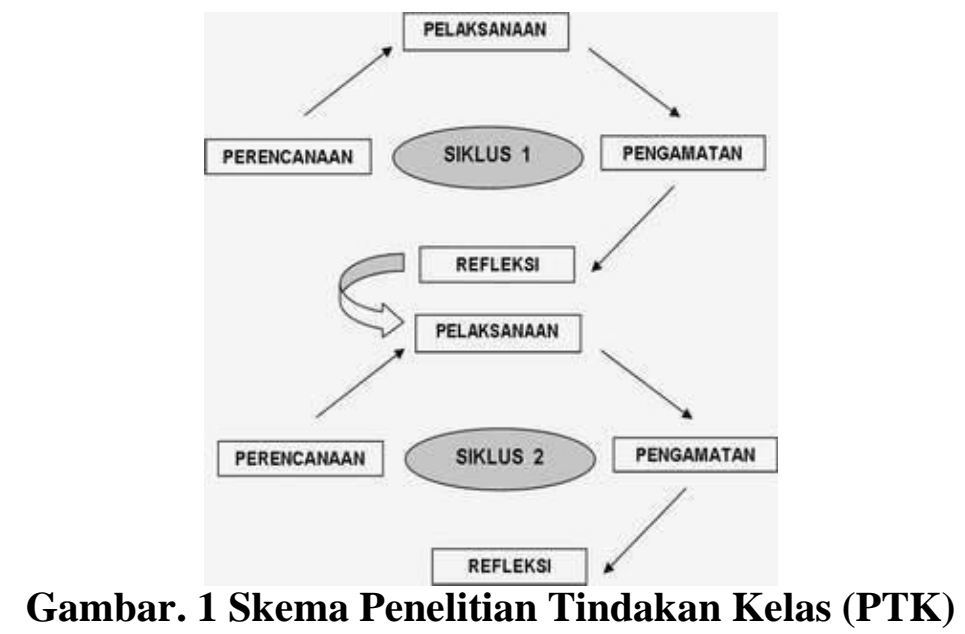

\section{Tenik Analisis Data}

Teknik analisis data adalah proses mencari dan menyusun secara sistematis data yang diperoleh dari hasil wawancara, catatan lapangan dan dokumentasi dengan cara mengorganisasikan data dalam kategori, menjabarkan kedalam unit-unit, menggunakan sintesa, menyusun kedalam pola, memilih mana yang penting dan yang akan dipelajari dan membuat kesimpulan sehingga mudah dipahami oleh diri sendiri atau orang lain.

Tabel 1. Teknik análisis data

\begin{tabular}{|l|l|l|}
\hline \multicolumn{1}{|c|}{ Jenis Data } & \multicolumn{1}{c|}{ Instrumen Pengumpul Data } & \multicolumn{1}{c|}{ Cara Pengumpulan Data } \\
\hline Aktivitas belajar siswa & lembar observasi & Observasi \\
\hline Hasil belajar siswa & Tes hasil belajar & Tes \\
\hline
\end{tabular}

Dalam penelitian ini yang menjadi indikator keberhasilan setelah pelaksanaan tindakan adalah meningkatnya aktivitas belajar siswa dalam proses pembelajaran Fisika yang dapat dilihat melalui analisis data. Apabila persentase di indikator yang telah ditentukan mencapai $\geq$ 70\% maka dapat dikatakan pemanfaatan Edmodo dapat meningkatkan aktivitas belajar siswa. Selain itu, meningkatnya hasil belajar siswa setelah pelaksanaan tindakan dapat dilihat melalui peningkatan nilai dari siklus I ke siklus selanjutnya. Apabila jumlah siswa yang memperoleh nilai sama atau lebih besar dari nilai KKM yaitu 71 mencapai $\geq 75 \%$ siswa, maka dapat dikatakan pemanfaatan Edmodo mampu meningkatkan hasil belajar siswa.

\section{HASIL DAN PEMBAHASAN}

Hasil

Berikut ini merupakan tabel aktivitas dan hasil belajar siswa kelas XI Kimia 3 pada observasi awal: 
Vol. 1 No. 4 Oktober 2021 e-ISSN : 2774-6283 | p-ISSN : 2775-0019

Tabel 2. Aktivitas Belajar Siswa Pada Observasi Awal

\begin{tabular}{|l|c|c|c|c|}
\hline No. & Kelas & Jumlah Siswa & Persentase Aktivitas Belajar & Kriteria \\
\hline 1 & XI Kimia 1 & 36 & $77 \%$ & Aktif \\
\hline 2 & XI Kimia 2 & 36 & $65 \%$ & Aktif \\
\hline 3 & XI Kimia 3 & 36 & $45 \%$ & Kurang Aktif \\
\hline
\end{tabular}

Tabel 3. Hasil Belajar Siswa Pada Observasi Awal

\begin{tabular}{|l|c|c|}
\hline No. & Kelas & Rata-Rata Nilai \\
\hline 1 & XI Kimia 1 & 74,9 \\
\hline 2 & XI Kimia 2 & 74,6 \\
\hline 3 & XI Kimia 3 & 66,7 \\
\hline
\end{tabular}

Berdasarkan tabel diatas, skor aktivitas tertinggi pada kelas XI Kimia 1 dan skor terendah pada kelas XI Kimia 3. Hasil Belajar pada observasi awal menunjukan bahwa nilai rata-rata tertinggi pada kelas XI Kimia 1 dengan nilai 74,9 dan terendah pada XI Kimia 3 dengan nilai rata-rata 66,7. Hasil observasi awal tersebut menunjukan bahwa aktivitas dan hasil belajar terendah terjadi pada kelas XI kimia 3. Sesuai dengan hasil observasi awal dan rekomendasi dari guru, maka perlu adanya peningkatan kualitas pembelajaran pada kelas XI Kimia 3.

Pelaksanaan penelitian pada siklus 1 dan siklus 2 dilakukan pada kelas maya menggunakan aplikasi Edmodo. Kegiatan yang diteliti untuk mengukur aktivitas belajar siswa adalah mengunduh bahan ajar, menanggapi pertanyaan atau merumuskan pertanyaan, mengunggah hasil pekerjaan ke dalam Edmodo, mengumpulkan tugas tepat pada waktunya dan mengerjakan soal dalam Edmodo.

Hasil observasi aktivitas belajar pada siklus 1 dan 2 menunjukkan adanya peningkatan menjadi $62 \%$ dan $92 \%$. Hal tersebut ditunjukkan dengan data pada tabel berikut ini:

Tabel 4. Data Hasil Observasi Aktivitas Belajar Siklus 1 dan 2

\begin{tabular}{|c|l|c|c|c|}
\hline No. & \multicolumn{1}{|c|}{ Indikator } & $\begin{array}{c}\text { Sebelum } \\
\text { Tindakan }\end{array}$ & Siklus 1 & Siklus 2 \\
\hline 1 & Mengunduh bahan ajar & $53 \%$ & $78 \%$ & $97 \%$ \\
\hline 2 & $\begin{array}{l}\text { Menanggapi pertanyaan atau merumuskan } \\
\text { pertanyaan }\end{array}$ & $36 \%$ & $42 \%$ & $83 \%$ \\
\hline 3 & $\begin{array}{l}\text { Mengunggah hasil pekerjaan ke dalam } \\
\text { Edmodo }\end{array}$ & $56 \%$ & $72 \%$ & $94 \%$ \\
\hline 4 & Mengumpulkan tugas tepat pada waktunya & $36 \%$ & $53 \%$ & $89 \%$ \\
\hline 5 & Mengerjakan soal dalam Edmodo & $44 \%$ & $67 \%$ & $97 \%$ \\
\hline & \multicolumn{1}{|c|}{ Rata-rata Aktivitas Belajar Siswa } & $45 \%$ & $62 \%$ & $92 \%$ \\
\hline
\end{tabular}

Berdasarkan pada tabel diatas, maka aktivitas siswa menunjukkan adanya peningkatan dari skor pada kondisi awal sebelum adanya tindakan. Skor pada kondisi awal sebesar $45 \%$ dengan kategori kurang aktif, menjadi 92\% pada siklus 2 dengan kategori sangat aktif.

Hasil belajar pada siklus 1 dan siklus 2 juga menunjukkan adanya peningkatan dari sebelumnya. Berdasarkan evaluasi pembelajaran yang dilakukan pada pertemuan kedua diperoleh hasil belajar dengan rata-rata sebesar 72,37 pada siklus 1 dan 80,10 pada siklus 2 . Hal ini menunjukkan adanya peningkatan dari kondisi awal rata-rata nilai kelas XI Kimia 3 sebesar 66,7. Berikut ini tabel hasil nilai rata-rata siswa kelas XI Kimia 3 :

Tabel 5. Hasil Belajar Siswa

\begin{tabular}{|l|c|c|}
\hline No. & Kelas & Rata-Rata Nilai \\
\hline 1 & Kondisi Awal & 66,7 \\
\hline
\end{tabular}




\begin{tabular}{|l|l|l|}
\hline 2 & Siklus 1 & 72,37 \\
\hline 3 & Siklus 2 & 80,10 \\
\hline
\end{tabular}

Berdasarkan data diatas, maka dapat disimpulkan bahwa terjadi peningkatan dari kondisi awal nilai rata-rata sebesar 66,7 menjadi 72,37 pada siklus 1 dan 80,10 pada siklus 2 . Peningkatan dari kondisi awal ke siklus 1 dan siklus 2 dapat ditunjukkan dengan diagram berikut:

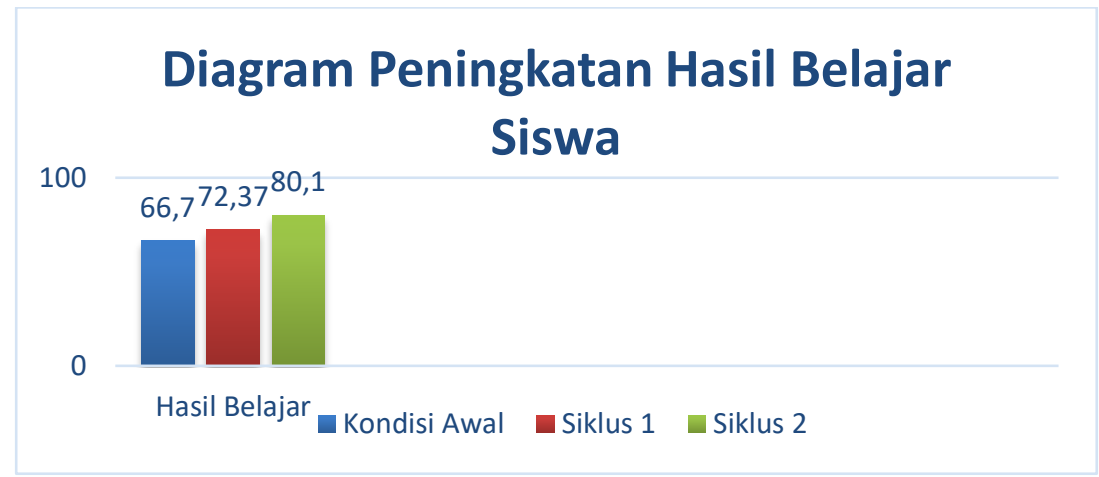

Gambar 2. Diagram peningkatan hasil belajar siswa

\section{Pembahasan}

Hasil penelitian menunjukkan bahwa penggunaan media Edmodo dapat meningkatkan aktivitas dan hasil belajar siswa kelas XI Kimia 3 SMKN 1 Gunungputri. Aktivitas belajar siswa berupa aktivitas mengunduh bahan ajar, menanggapi pertanyaan atau merumuskan pertanyaan, mengunggah hasil pekerjaan ke dalam Edmodo, mengumpulkan tugas tepat pada waktunya dan mengerjakan soal dalam Edmodo meningkat dari kategori kurang aktif menjadi sangat aktif. Hasil belajar siswa juga membuktikan bahwa siswa kelas XI Kimia 3 dapat mencapai ketuntasan kelas yaitu sebesar 80,10 serta mampu mencapai KKM sekolah yaitu 71. Hal ini membuktikan bahwa hipotesis yang diajukan dalam penelitian ini terbukti. Hasil penelitian ini sejalan dengan penelitian yang telah dilakukan oleh Wasis (2013) bahwa penggunaan media pembelajaran fisika dengan e-learning berbasis Edmodo Blog Education dapat meningkatkan respons motivasi siswa. Penelitian lain yang sejalan juga dengan hasil penelitian ini dilakukan oleh Santhy (2016) yang menyatakan bahwa penggunaan media pembelajaran Edmodo dapat meningkatkan aktivitas dan hasil belajar siswa.

\section{KESIMPULAN}

Berdasarkan hasil penelitian dan analisis data yang dilakukan dapat disimpulkan bahwa penelitian tindakan kelas tentang pemanfaatan Edmodo dalam pembelajaran di SMKN I Gunungputri pada saat Praktek Kerja Lapangan (PKL) dapat meningkatkan aktivitas dan hasil belajar. Skor aktivitas siswa menunjukkan adanya peningkatan dari skor pada kondisi awal (sebelum adanya tindakan). Skor pada kondisi awal sebesar $45 \%$ dengan kategori kurang aktif menjadi $92 \%$ pada siklus 2 dengan kategori sangat aktif. Penggunaan media Edmodo juga dapat meningkatkan hasil belajar siswa. peningkatan dari kondisi awal nilai rata-rata sebesar 66,7 menjadi 72,37 pada siklus 1 dan 80,10 pada siklus 2. Kesimpulannya Aktivitas dan hasil belajar siswa kelas XI Kimia 3 mengalami peningkatan setelah digunakannya Edmodo dalam proses pembalajaran.

\section{DAFTAR PUSTAKA}

Arikunto, S., Suhardjono., \& Supardi. (2011). Penelitian Tindakan Kelas, Jakarta: PT Bumi Aksara.

Bala subrama niana, Kandappan., Jaykumar., \& Leena, N. K. (2014). A study on "Student preference towards the use of Edmodo as a learning platform to create responsible 
learning environment" Prosiding, 5th Asia Euro Conference. Selangor : School of Hospitality, Tourism and Culinary Arts, Taylor's University, Malaysia.

Dwiharja \& Mahendrati, L. (2015, 9 Mei 2015). Memanfaatkan Edmodo Sebagai Media Pembelajaran Akuntansi : Prosiding Seminar Nasional, Universitas Negeri Surabaya.

Effendi, Empy \& Hartono, Zhuang. (2005). E- Learning: Konsep dan Aplikasi. Yogyakarta: Andi Offset.

Hamalik, O. (2009). Kurikulum dan Pembelajaran. Jakarta: Bumi Aksara.

Santhy R. P., Wahyuni, A., \& Suharso. (2016). Penggunaan Media Pembelajaran Edmodo Untuk Meningkatkan Aktivtas dan Hasil Belajar Siswa Kelas X Pemasaran di SMK Negeri 1 Jember Tahun Ajaran 2016/2017. Jurnal UNNEJ Vol 11 No. 2

Sardiman A, M. (2012). Interaksi dan Motivasi Belajar-Mengajar. Jakarta: Raja Grafindo Persada.

Soekartawi. (2007). Merancang dan Menyelenggarakan E-learning. Yogyakarta: Ardana Media.

Sudibjo, A., \& Wasis. (2013). Penggunaan media pembelajaran Fisika dengan E-Learning berbasis Edmodo Blog Education pada materi Alat Optik untuk meningkatkan respos motivasi dan hasil belajar siswa di SMP Negeri 4 Surabaya: Jurnal Inovasi Pendidikan Fisika Vol. 02 No. 03 Tahun 2013, hal 187 - 190.

Sudjana, Nana. (2006). Penilaian Hasil Proses Belajar Mengajar, Bandung: Rosdakarya. 